\section{Surface Treatments for Repair of Feldspathic, Leucite- and Lithium Disilicate-Reinforced Glass Ceramics Using Composite Resin}

Christian Alencar Neis ${ }^{1}$, Nadine Luísa Guimarães Albuquerque ${ }^{2}$, Ivo de Souza Albuquerque ${ }^{2}$, Erica Alves Gomes ${ }^{1}$, Celso Bernardo de Souza-Filho ${ }^{1}$, Victor Pinheiro Feitosa ${ }^{2}$, Aloisio Oro Spazzin ${ }^{1}$, Atais Bacchi ${ }^{1,3}$
'IMED - Meridional University, School of Dentistry, Department of Prosthodontics and Dental Materials, Passo Fundo, RS, Brazil ${ }^{2}$ UFC - Federal University of Ceará, School of Pharmacy, Dentistry and Nursing, Department of Restorative Dentistry, Fortaleza, CE, Brazil ${ }^{3}$ Piracicaba Dental School, UNICAMP - University of Campinas, Department of Prosthodontics and Periodontics, Piracicaba, SP, Brazil

Correspondence: Atais Bacchi, Rua Evaristo Tagliari, 430/102, 99010-470 Passo Fundo, RS, Brasil. Tel: +55-54-3045-6100. e-mail: atais_bacchi@yahoo.com.br

Key Words: dental ceramics, repairs, surface treatments.

\section{Introduction}

Ceramic restorations have been employed for their innumerous advantages such as color stability, low thermal conductivity, resistance to wear and biocompatibility. However, ceramics without metallic support are prone to crack propagation (1). The feldspathic ceramics used as veneer are commonly affected by shipping, fracture or excessive wear, mainly when supported by zirconia frameworks (2). In this way, direct repair with a composite resin appears as an attractive alternative due to the low cost, fast resolution, and preservation of supporting structures (3-5).

Glass-reinforced ceramics have been also emphasized. Actually, the most popular are the leucite- and the lithium disilicate-reinforced ones. Both may be used to obtain veneers, inlays, onlays and crowns. Monolithic application of these ceramics for crowns has been employed to provide higher resistance than the bi-layer restorations (6), although fractures and wear may also occur in this type of restoration.

Surface preparation in fractured ceramic must be performed in the repair procedure that involves mechanical or chemical surface preparations to create irregularities on the surface. Bonding components are also required for the adhesion to restorative material. Traditionally, surface treatment for ceramics involves roughening with diamond burs (7-9), etching with hydrofluoric acid $(8,10-12)$ or tribochemical process based on silica-coated aluminumoxide particles (11-17). For restorative material bonding, use of silane is recommended for glasses and porcelains in order to obtain a mesh of siloxane with the silica on the ceramic surface, to improve the bond strength between the ceramic and luting material and to increase the surface energy for adhesive application (18).

The aim of this study was to evaluate the microtensile bond strength after composite resin repairs in glassceramics after different surface treatments. The null hypothesis of the study was that there is no difference among the tested techniques.

\section{Material and Methods}

The following ceramics were used in this study: feldspathic ceramic (Vita VM7, Vita Zahnfabrik, Bad Säckingen, Germany), leucite-reinforced glass-ceramic (IPS Empress, Ivoclar Vivadent, Schaan, Liechtenstein), lithium disilicate-reinforced glass ceramic (IPS E.max Press, Ivoclar Vivadent). Twelve blocks $(10.0 \times 7.0 \times 3.0 \mathrm{~mm})$ were obtained 
for each ceramic and aged in distilled water for 3 months at $37{ }^{\circ} \mathrm{C}$. The bonding surface of all ceramic blocks was abraded for $15 \mathrm{~s}$ with 600-grit silicon carbide paper and cleaned using ultrasound for $10 \mathrm{~min}$.

The blocks were randomly divided $(n=3)$ in four groups according surface treatments, as follows: GC (control group) - no surface treatment; GDB: surface wear by 30- $\mu \mathrm{m}$-grit diamond bur during $20 \mathrm{~s}$ under water cooling; GHF: hydrofluoric acid (10\%) during $90 \mathrm{~s}$ for feldspathic ceramic, $60 \mathrm{~s}$ for leucite-reinforced glass-ceramic, and $20 \mathrm{~s}$ for lithium disilicate-reinforced glass ceramic; GT: tribochemical process: sandblasting with silica-coated aluminum oxide ( $45-\mu \mathrm{m}$ size particles) for $20 \mathrm{~s}$, at a distance of $10 \mathrm{~mm}$, perpendicular to the adhesion surface, under 2.8 bar pressure.

In all ceramic blocks, the surface treated by the different protocols was cleaned with 37\% phosphoric acid (Condac 37, FGM Dental Products, Joinvile, SC, Brazil) for $30 \mathrm{~s}$, followed by silane application (Angelus Dental Products, Londrina, PR, Brazil) for $1 \mathrm{~min}$. An adhesive system was used as bonding agent (Adapter Singlebond 2; 3M/ESPE, St. Paul, $M N$, USA) and light-cured for $20 \mathrm{~s}$ using an irradiance of $800 \mathrm{~mW} / \mathrm{cm}$ (BluePhase LED; Ivoclar Vivadent). Composite resin (FiltekZ350; 3M/ESPE) was used as restorative material by the incremental technique and light-cured for $30 \mathrm{~s}$ as previously described until obtaining a 3-mm thickness. A single operator performed the complete repair process.

Samples were submitted to thermocycling process $\left(10,000\right.$ cycles, between $5^{\circ} \mathrm{C}$ and $55^{\circ} \mathrm{C}$ for $30 \mathrm{~s}$ in each bath). After the ageing procedure, the specimens were sectioned in serial slabs (1 $\mathrm{mm}$ thick) using a diamond-embedded blade under continuous water irrigation (Buehler, Lake Bluff, IL, USA) and subsequently in $1 \mathrm{~mm}^{2}$ match-sticks and subjected to the microtensile bond strength $(\mu \mathrm{TBS})$ evaluation in a universal testing machine (EZ-test, Shimadzu Co., Kyoto, Kansai, Japan) at a crosshead speed of $0.5 \mathrm{~mm} /$ min. Data were obtained in MPa. The failure pattern was evaluated by a stereomicroscope (Leica Microsystems, Wetzler, Germany) at 60x magnification and failures were

Table 1. Mean values (MPa) and standard deviations for the different groups in each ceramic

\begin{tabular}{lccc}
\hline Groups & Feldspathic & Leucite-reinforced & $\begin{array}{c}\text { Lithium disilicate- } \\
\text { reinforced }\end{array}$ \\
\hline GC & $9.0(10.0) \mathrm{B} \mathrm{ab}$ & $17.9(3.4) \mathrm{A} \mathrm{a}$ & $4.6(1.3) \mathrm{B} \mathrm{b}$ \\
$\mathrm{GDB}$ & $13.9(1.99) \mathrm{B} \mathrm{a}$ & $22.4(4.4) \mathrm{A} \mathrm{a}$ & $4.4(2.6) \mathrm{C} \mathrm{b}$ \\
$\mathrm{GHF}$ & $14.4(4.44) \mathrm{B} \mathrm{a}$ & $3.7(0.4) \mathrm{C} \mathrm{b}$ & $21.1(5.2) \mathrm{A} \mathrm{a}$ \\
$\mathrm{GT}$ & $0(0) \mathrm{C} \mathrm{b}$ & $21.7(2.5) \mathrm{A} \mathrm{a}$ & $8.3(5.5) \mathrm{B} \mathrm{b}$ \\
\hline
\end{tabular}

Different uppercase letters indicate in rows and lowercase letters in columns indicate statistically significant difference $(p=0.05)$. classified as adhesive, mixed or cohesive.

Data were processed using SPSS software (version 20; IBM, Armonk, NY, USA) by two-way ANOVA. Post-hoc tests were calculated using the Tukey's test. All tests were conducted at 95\% confidence interval ( $\alpha=0.05)$.

\section{Results}

Mean values (MPa) and standard deviation for all groups are presented in Table 1. Statistical analysis revealed that for feldspathic ceramic no experimental treatment increased $\mu$ TBS in comparison with GC. However, the group subjected to tribochemical process had significantly lower results than the other groups $(\mathrm{p}<0.001)$, presenting pre-test failures in all sticks. For the leucite-reinforced glass ceramic (IPS Empress), GDB and GT did not differ from GC, while GHF showed lower $\mu$ TBS values $(p<0.001)$. For the lithium disilicate-reinforced glass ceramic (IPS E.max press), GHF showed significantly higher $\mu$ TBS values than $G C, G B D$ and GT ( $p<0.001)$, which were similar among them. Interaction between the factors (ceramic type and surface treatment) was statistically significant $(p<0.001)$.

Failure patterns are presented in Table 2. Predominance of adhesive failures ( $>85 \%$ in all groups) was observed. Mixed failures presented a small proportion $(<8 \%$ in all groups) and cohesive failures did not exceed $5.2 \%$ in all groups.

\section{Discussion}

This study showed that the surface treatment influenced the $\mu$ TBS of all tested ceramics. Therefore, the null hypothesis

Table 2. Failure patterns (\%) for the different surface treatments and ceramics features

\begin{tabular}{lcccc}
\hline \multirow{2}{*}{ Group } & Ceramic & \multicolumn{3}{c}{ Failure mode (\%) } \\
\cline { 3 - 5 } & & Adhesive & Mixed & Cohesive \\
\hline GC & Feldspathic & 95.3 & 4.7 & 0 \\
GC & Leucite & 94.8 & 5.2 & 0 \\
GC & Disilicate & 93.3 & 6.7 & 0 \\
GDB & Feldspathic & 89.8 & 5.8 & 4.4 \\
GDB & Leucite & 91.3 & 7.6 & 1.1 \\
GDB & Disilicate & 93.9 & 6.1 & 0 \\
GHF & Feldspathic & 87.7 & 7.1 & 5.2 \\
GHF & Leucite & 91.8 & 6.0 & 2.2 \\
GHF & Disilicate & 96.5 & 3.5 & 0 \\
GT & Feldspathic & 100.0 & 0 & 0 \\
GT & Leucite & 95.5 & 3.1 & 1.4 \\
GT & Disilicate & 96.4 & 2.4 & 1.2 \\
\hline
\end{tabular}


was rejected. Additionally, it was observed that the success of surface treatment depends on the ceramic type. For the lithium disilicate-reinforced glass ceramic, the etching with hydrofluoric acid promoted the highest $\mu$ TBS values, which is in agreement with Colares et al. (10). This ceramic has the lowest vitreous proportion among the ceramics tested in this study. Therefore, it seems that the chemical conditioning is most efficient to infiltrate and remove the vitreous phase, creating irregularities in the surface. For leucitereinforced glass ceramic, the etching with hydrofluoric acid was the only tested surface treatment that showed lower $\mu$ TBS compared with control and the other tested groups. Since this ceramic has a higher vitreous proportion in comparison to lithium disilicate, it was suggested that mechanical treatments such as the use of diamond burs are more efficient to create irregularities. The success of tribochemical process for leucite-reinforced glass ceramic, which involves the creation of irregularities by sandblasting with aluminum oxide silica-coated particles and chemical improvement by silica deposition on the ceramic surface, is also in agreement with previous reports (14).

For the feldspathic ceramic, the tribochemical process was the only tested surface treatment that promoted $\vec{z}$ lower values of $\mu$ TBS in comparison with other tested groups. In fact, this type of ceramic showed pre-testing failures during the tribochemical process for all samples during the stick preparation, like weak bond strength, which lead to failures previous to the testing method, even during stick preparation or handling them, characterizing a bond strength equal to zero in the results section. This process is characterized by silica deposition on the ceramic surface, used mainly for bonding on crystalline ceramics as zirconia and alumina. Therefore, it may be suggested that silica deposition on feldspathic ceramic has a long-term low stability. Nevertheless, the present results are different from those of Attia (7) who found that the tribochemical treatment showed similar values of $\mu$ TBS in relation to diamond bur preparation and also diverge from the study of Melo et al. (11) where tribochemical process was similar to etching with hydrofluoric acid. However, it is important to highlight that those studies did not use the ageing process for the bonded interface, as the thermocycling used in this study, which may have caused the interface degradation. As regards the success of other surface treatments (groups GHF and GDB) used in this study to repair feldspathic ceramics, they are in agreement with other studies $(7,8,11)$.

These observations for efficacy of mechanical or chemical methods for conditioning depending on the ceramic's type are also supported by the data of control group for all ceramics. The silicone grit paper used in all samples to remove the superficial ceramic layer simulating the repair and also used to standardize the surface roughness probably acts as a mechanical preparation providing roughness on the ceramic surface. In this way, the results of this study showed $\mu$ TBS values in $\mathrm{GC}$ of feldspathic and leucite-reinforced ceramic comparable to those of other mechanical surface treatments. However, for lithium disilicate ceramic the GC was similar to other mechanical treatments, which were significantly lower than HF etching.

The failure patterns observed in this study showed a great prevalence of adhesive failures for all groups, ranging from 85 to $100 \%$. Based on these results, it was not possible to establish a relation of failure pattern with $\mu$ TBS for the used surface treatments. Other analyses showed that adhesive failures are the most observed for repaired ceramic interfaces (16), some studies presenting $100 \%$ prevailance $(12,14)$. This information may suggest that bond strength of repairs on ceramic surfaces are not comparable to the bulk strength of the materials, thus its clinical prognostic success may be related to application in areas of low occlusal load.

Ceramic fractures may result from several factors, such as inadequate occlusal adjustment, failure in the bonding interface, internal porosities, parafunctional habits, and internal stress from the manufacturing process (1). The repair is characterized by a faster and low-cost method if compared to replacement of the entire restoration (35). This study has shown that using the correct surface treatment for each ceramic is the key for success in repair procedure. The methods here employed are traditional treatments used in dental clinic. Roughness with diamond bur might be considered the most practical among them because it does not require any additional precaution or protection of the patient than those traditionally used and does not need the use of other apparatus than the traditional burs. Etching with hydrofluoric acid needs complete rubber dam isolation of the teeth to be applied on, as it is irritating to oral tissues. The tribochemical process also needs rubber dam isolation for protecting the mouth from the sandblasted silica-coated aluminum oxide particles.

Within the limitations of this study, considering the evaluated materials and techniques, it may be concluded that diamond burs can be used as surface treatment for repairs in feldspathic and leucite-reinforced ceramics; hydrofluoric acid etching is indicated for repair of lithium disilicate-reinforced ceramic and tribochemical process in successfully used for repairs of leucite-reinforced ceramic. The success of surface treatment depends on the type of ceramic to which it is applied.

\section{Resumo}

0 objetivo deste estudo foi avaliar a eficácia de diferentes 
condicionamentos de superfície na resistência de união de reparos de compósitos restauradores em três tipos de cerâmicas odontológicas: reforçada por dissilicato de lítio, reforçada por leucita e feldspática. Foram confeccionados 12 blocos para cada tipo de cerâmica $(n=3)$ e armazenados por 3 meses em água destilada a $37{ }^{\circ} \mathrm{C}$. A superfície de união das cerâmicas foi regularizada com lixa de granulação 600 por 15 s e lavadas em ultrassom por $10 \mathrm{~min}$. Os tratamentos de superficie para cada cerâmica foram: GC (controle) - nenhum; GPD - ponta diamantada com $30 \mu \mathrm{m}$ de granulação; GAF - ácido hidrofluoridrico a 10\%; GJ jateamento com partículas de óxido de alumínio revestido por sílica (45 $\mu \mathrm{m}$ - tamanho das partículas). Após, foi realizada a limpeza da superfície com ácido fosfórico a 7\% por $20 \mathrm{~s}$, seguido de silano e adesivo. Como material restaurador foi utilizada resina composta. Após o reparo, as amostras foram submetidas a ciclagem térmica $(10,000$ ciclos entre 5 ${ }^{\circ} \mathrm{C}$ e $55{ }^{\circ} \mathrm{C}$, por 30 s). Na sequência, as amostras foram seccionadas em palitos de aproximadamente $1,0 \mathrm{~mm}^{2}$ e levadas ao teste de tração em uma máquina de ensaios universal à velocidade de $0,5 \mathrm{~mm} / \mathrm{min}$. Os dados obtidos foram comparados estatisticamente por ANOVA de dois fatores e teste de Tukey $(\alpha=0,05)$. Sugere-se que o desgaste da superfície com ponta diamantada é mais indicado para a cerâmica feldspática e cerâmica reforçada por leucita, enquanto o condicionamento com ácido fluorídrico é indicado para reparos em cerâmica reforçada por dissilicato de lítio. 0 jateamento com partículas de óxido de alumínio revestido por sílica mostrou-se aplicável à cerâmica reforçada por leucita. Predominancia de fraturas adesivas acima de $85 \%$ foi observada para todos os grupos. Este estudo demonstrou que o sucesso dos tratamentos de superfície depende do tipo de cerâmica a que são aplicados.

\section{Acknowledgements}

The authors would like to thank the Meridional Laboratory, Passo Fundo, $\mathrm{RS}$, Brazil, for the valuable assistance with the sintering process of ceramics.

\section{References}

1. Rekow ED, Silva NRFA, Coelho PG, Zhang $Y$, Guess $P$, Thompson VP. Performance of dental ceramics: challenges for improvements. J Dent Res 2011;90:937-952.

2. Della Bona A, Kelly JR. The clinical success of all-ceramic restorations. J Am Dent Assoc 2008;139;8S-13S.

3. Raposo LHA, Neiva NA, Silva GR, Carlo HL, Mota AS, Prado CJ, et al.. Ceramic restoration repair: report of two cases. J Appl Oral Sci 2009;17:140-144.

4. Kimmich, M, Stappert, C. Intraoral treatment of veneering porcelain chipping of fixed dental restorations: A review and clinical application, J Am Dent Assoc 2013;144:31-44.

5. Reston EG, Filho SC, Arossi G, Cogo RB, Rocha CS, Closs LQ. Repairing ceramic restorations: final solution or alternative procedure? Oper Dent
2008:33:461-466.

6. Guess PC, Zavanelli RA, Silva NRFA, Bonfante EA, Coelho PG, Thompson VP. Monolithic CAD/CAM lithium disilicate versus veneered Y-TZP crowns: comparison of failure modes and reliability after fatigue. Int J Prosthodont 2010;23:434-442.

7. Attia A. Influence of surface treatment and cyclic loading on the durability of repaired all-ceramic crowns. J Appl Oral Sci 2010;18:194200.

8. Gourav $R$, Ariga P, Jain AR, Philip JM. Effect of four different surface treatments on shear bond strength of three porcelain repair systems: An in vitro study. J Conserv Dent 2013;16:208-212.

9. Jain $\mathrm{S}$, Parkash $\mathrm{H}$, Gupta $\mathrm{S}$, Bhargava A. To evaluate the effect of various surface treatments on the shear bond strength of three different intraoral ceramic repair systems: An in vitro study. J Indian Prosthodont Soc 2013;13:315-320.

10. Colares RCR, Neri JR, Souza AMB, Pontes KMF, Mendonça JS, Santiago SL. Effect of surface pretreatments on the microtensile bond strength of lithium-disilicate ceramic repaired with composite resin. Braz Dent J 2013;24:349-352.

11. Melo RM, Valandro LF, Bottino MA. Microtensile bond strength of a repair composite to leucite-reinforced feldspathic ceramic. Braz Dent J 2007;18:314-319.

12. Ozcan M, Valandro LF, Pereira SMB, Amaral R, Bottino MA, Pekkan G. Effect of surface conditioning modalities on the repair bond strength of resin composite to the zirconia core / veneering ceramic complex. $J$ Adhes Dent 2013;15:207-210.

13. Han $\mathrm{IH}$, Kang DW, Chung $\mathrm{CH}$, Choe $\mathrm{HC}$, Son MK. Effect of various intraoral repair systems on the shear bond strength of composite resin to zirconia. J Adv Prosthodont 2013;5:248-255.

14. Blum IR, Nikolinakos N, Lynch CD, Wilson NHF, Millar BJ, Jagger DC. An in vitro comparison of four intra-oral ceramic repair systems. Journal of Dentistry 2012;40:906-912.

15. Cristoforides $P$, Amaral R, May LG, Bottino MA, Valandro LF. Composite resin to yttria stabilized tetragonal zirconia polycrystal bonding: comparison of repair methods. Oper Dent 2012; 37:263-271.

16. Panah FG, Rezai SMM, Ahmadian L. The influence of ceramic surface treatments on the micro-shear bond strength of composite resin to IPS Empress 2. J Prosthodont 2008;17:409-414.

17. Lee SJ, Cheong CW, Wright RF, Chang BM. Bond strength of the porcelain repair system to all-ceramic copings and porcelain. J Prosthodont 2014;23:112-116.

18. Matinlinna JP, Vallittu PK. Bonding of resin composites to etchable ceramic surfaces -can insight review of the chemical aspects on surface conditioning. J Oral Rehabil 2007;34:622-630.

Received February 12, 2014 Accepted October 28, 2014 